Eur. J. Clin. Chem. Clin. Biochem.

Vol. 32, 1994, pp. 837-842

(C) 1994 Walter de Gruyter \& Co.

Berlin $\cdot$ New York

\title{
A Comparative Study of the Concentrations of Hypoxanthine, Xanthine, Uric Acid and Allantoin in the Peripheral Blood of Normals and Patients with Acute Myocardial Infarction and Other Ischaemic Diseases
}

By R. Kock', B. Delvoux ${ }^{1}$, M. Siginund ${ }^{2}$ and H. Greiling ${ }^{1}$

'Institute for Clinical Chemistry and Pathobiochemistry, Medical Faculty, University of Technology Aachen,
Aachen, Germany
2 Medical Clinic I, Medical Faculty, University of Technology Aachen, Aachen, Germany

(Received February 14/August 4, 1994)

Summary: The aim of this study was the elucidation of the role of the xanthine oxidoreductase in the purine metabolism in ischaemic diseases of man. The serum concentrations of hypoxanthine, xanthine, uric acid and allantoin were determined in peripheral blood samples from patients with angina pectoris, cerebral insult and myocardial infarction with thrombolytic therapy and were compared with the concentrations obtained for healthy males and females. No significant differences were observed for the serum hypoxanthine concentrations, xanthine concentrations, the sum (hypoxanthine + xanthine) and the ratio (xanthine/hypoxanthine) between the healthy males, healthy females, the patients suffering from angina pectoris and the patients suffering from cerebral insult. An increase of the serum xanthine concentration in patients with myocardial infarction indicates a significant metabolic involvement of xanthine oxidoreductase in this disease and therefore a possible role in the development of tissue damage in the postischaemic phase due to oxygen radicals generated by the oxidase activity of this enzyme.

The serum concentrations of uric acid and allantoin showed no differences between any of the studied groups. Study of the non-enzymatic oxidation of uric acid to allantoin by oxygen radicals, a relevant radical-scavenging mechanism in other diseases, provided no indication of an increased concentration of oxygen radicals due to the xanthine oxidoreductase reaction or other radical-producing mechanisms.

\section{Introduction}

Xanthine oxidoreductase (EC 1.2.3.2) is the terminal enzyme of purine metabolism. Physiologically this enzyme used $\mathrm{NAD}^{+}$as electron acceptor, but in ischaemia it may be converted from the dehydrogenase form to an oxidase form, which uses molecular oxygen as an electron acceptor (1). Several studies have been performed on the relevance of xanthine oxidase in tissue destruction by oxygen-derived radicals. De Scheerder concluded from the parallel coronary release of malondialdehyde and uric acid, that there is an enhanced unspecific oxidation of membrane phospholipids by oxygen-derived radicals produced by xanthine oxidase (2). In the present study the serum concentrations of hypo- xanthine, xanthine, uric acid and allantoin in samples from $\mathrm{n}=115$ patients with acute myocardial infarction were compared with those in samples from $n=180$ healthy males, $n=145$ healthy females, $n=45$ patients with angina pectoris and $n=19$ patients suffering from cerebral infarction. Furthermore the results of the serial determinations of the serum concentrations of hypoxanthine, xanthine, the sum (hypoxanthine + xanthine) and the ratio (xanthine/hypoxanthine) for $n=53$ patients with clinically diagnosed acute myocardial infarction were compared with classical clinical chemical markers for the diagnosis and follow-up of this disease. The method used for the simultaneous determination of hypoxanthine, xanthine, uric acid and allantoin from serum was presented in a previous publication (3). 

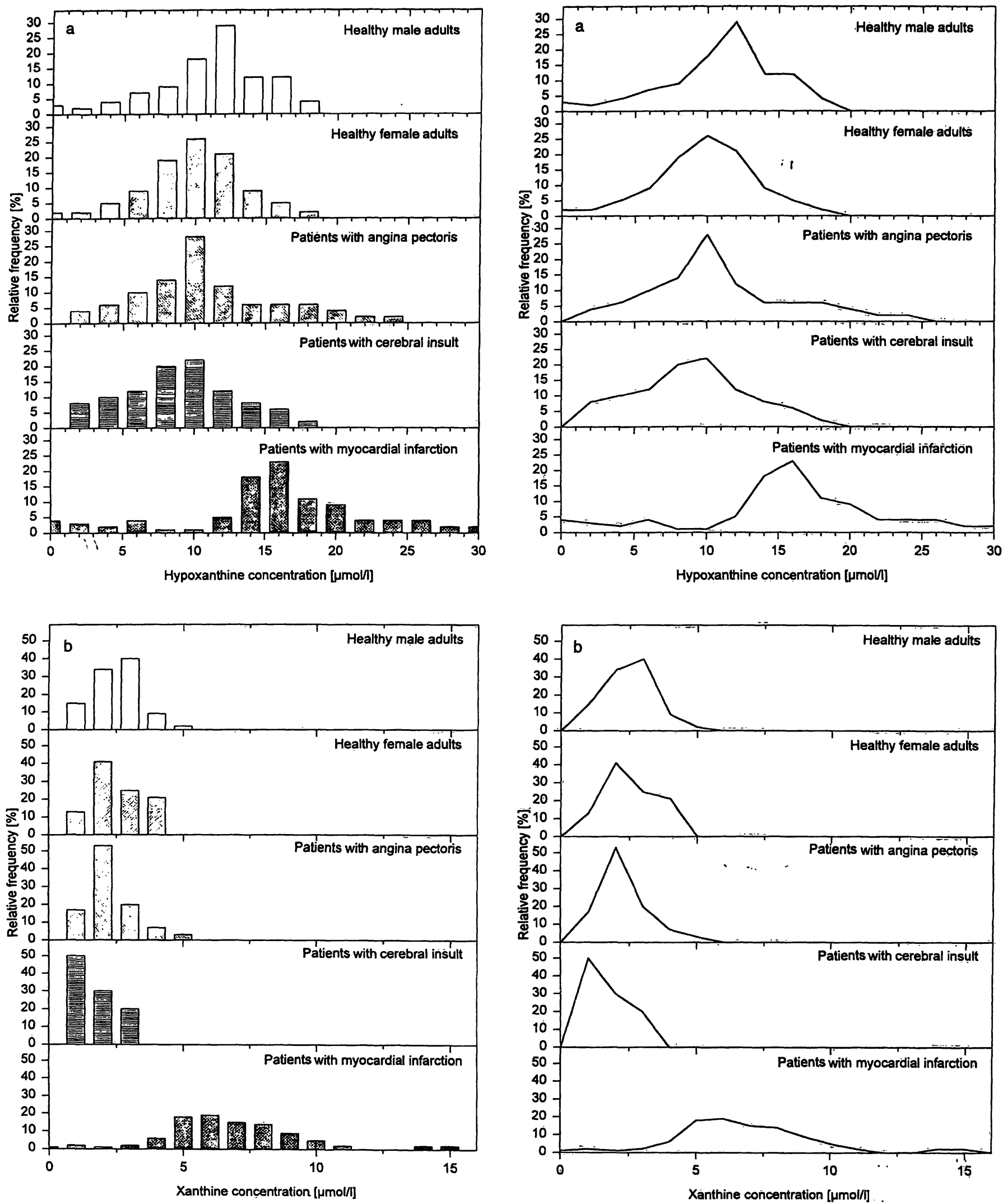

Fig. 1 a-b Distribution of serum hypoxanthine concentrations and serum xanthine concentrations for the reference groups (healthy males and healthy females), patients suffering from angina pec-

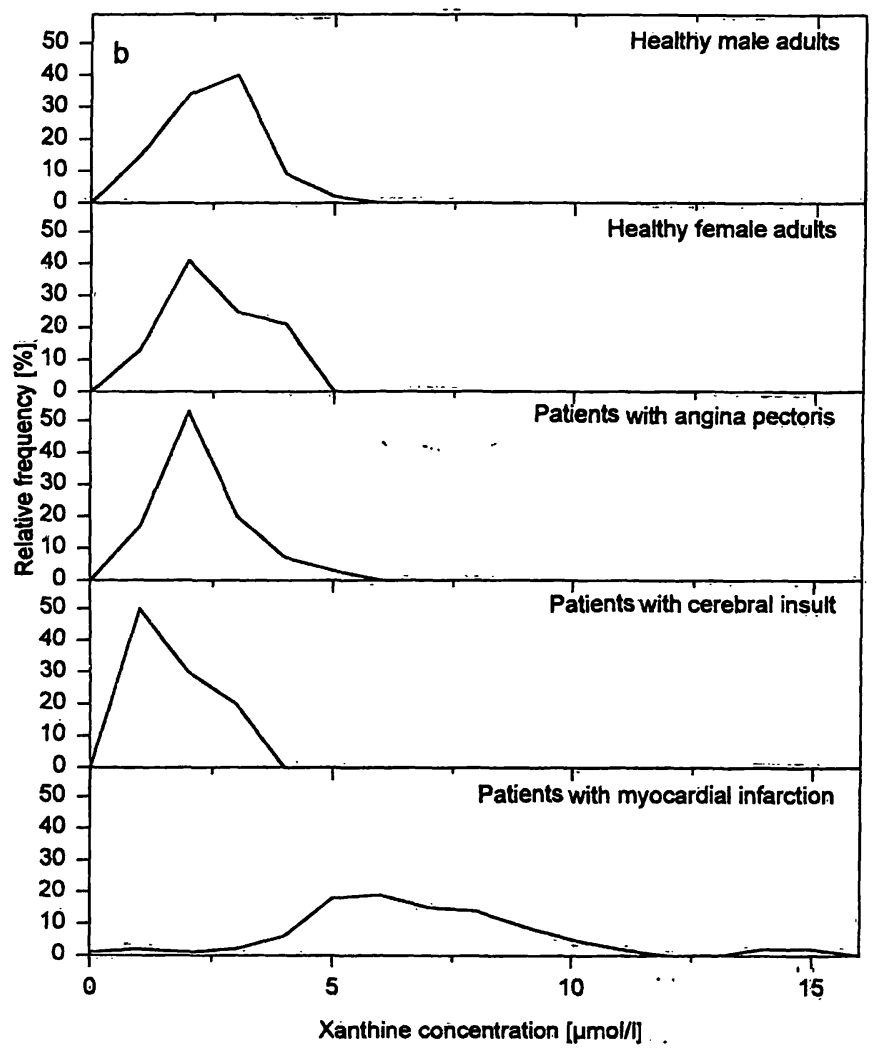

toris and patients suffering from cerebral insult versus patients with acute myocardial infarction.

\section{Materials and Methods}

\section{Chemicals}

For the preparation of standard solutions of allantoin, hypoxanthine and xanthine, materials of the highest available purity (SIGMA,

Munnich, Germany) were used. Uric acid was Standard Reference Material with a purity of $99.7 \%$ (SRM 913, National Bureau of Standards, Washington D. C. 20234). The reagents required for the determination of the enzyme activities of creatine kinase and creatine kinase isoenzyme $\mathrm{MB}$ wẹrè from Boehringer Mañnheim. 
All other chemicals were purchased from Merck (Darmstadt, Germany) and were of analytical grade; methanol was of HPLC-grade.

\section{Samples}

For the drawing blood the Sarstedt-system with separation-gel was used and the time between blood withdrawal and centrifugation never exceeded $30 \mathrm{~min}$.

The samples in this study were from 180 healthy adult males, 145 healthy adult females, 155 adult patients with acute myocardial infarction and successful thrombolytic therapy according to clinical observations, 45 patients suffering from angina pectoris, and 19 patients with a cerebral infarction. The patient samples were drawn within $3-7 \mathrm{~h}$ after hospitalization.

All the samples taken from 53 patients with acute myocardial infarction for diagnostic purposes and follow-up were analysed. These patients showed early reperfusion of the occluded coronary artery spontaneously or as a result of therapeutic lysis.

\section{High performance liquid chromatography}

HPLC was performed on a Waters chromatography system with a gradient pump Model 600, a Satellite WISP Model 700 and a tuneable wavelength detector Model 481. System control, data acquisition, integration and calibration were performed with the Waters Maxima 825 software. Chromatographic separations were performed as described in l.c. (3). For the determination of hypoxanthine, xanthine and uric acid, UV-detection was performed at 254 $\mathrm{nm}$ with a range of 0.005 absorbance units full scale and a time constant of $1.0 \mathrm{~s}$. For the determination of allantoin as described in 1.c. (3), UV-detection was performed at $360 \mathrm{~nm}$ with a range of 0.100 absorbance units full scale and a time constant of $1.0 \mathrm{~s}$.

The method used in this study had a detection limit for hypoxanthine of $1 \mathrm{pmol}$ and for xanthine of $1.5 \mathrm{pmol}$; since $50 \mu \mathrm{l}$ of fivefold diluted serum were injected, the lower concentration limit for hypoxanthine and xanthine was $0.1 \mu \mathrm{mol} / 1$ and $0.15 \mu \mathrm{mol} / 1$, respectively. For serum hypoxanthine concentrations of $5-50 \mu \mathrm{mol} / 1$ the coefficient of variation did not exceed $5 \%$; for xanthine concentrations of $2-20 \mu \mathrm{mol} / \mathrm{l}$ the imprecision was less than $7 \%$.

\section{Determination of enzyme activities}

The determination of the enzyme activities of creatine kinase and creatine kinase-MB were performed on a Hitachi 747 at $25^{\circ} \mathrm{C}$ with the reagent kits obtained from Boehringer Mannheim.

\section{Statistical procedures and calculations}

For data management, Microsoft Excel 3.0a (Microsoft GmbH, Munich, Germany) was used. Statistical treatments, including the calculation of the Bayesian parameters for the sample classification, were performed with the statistical package Sigmastat V1.02 (Jandel Scientific GmbH, Erkrath, Germany).

\section{Results}

Hypoxanthine and xanthine from single serum samples

In figure $1 a-b$ the distribution of the hypoxanthine and xanthine concentrations in sera from patients with myo-
Tab. 1 Results for the determination of hypoxanthine, xanthine, the sum (hypoxanthine + xanthine) and the ratio (xanthine/hypo- xanthine). The samples from the patients were drawn at the intensive care unit within $3-7 \mathrm{~h}$ after hospitalization.

\begin{tabular}{|c|c|c|c|c|c|c|c|c|}
\hline & $\mathrm{n}$ & & $\begin{array}{l}\text { Hypo- } \\
\text { xanthine } \\
{[\mu \mathrm{mol} / 1]}\end{array}$ & $\begin{array}{l}\text { Xanthine } \\
{[\mu \mathrm{mol} / 1]}\end{array}$ & $\begin{array}{l}\text { Hypo- } \\
\text { xanthine } \\
+ \text { Xanthine } \\
{[\mu \mathrm{mol} / 1]}\end{array}$ & $\begin{array}{l}\text { Xanthine/ } \\
\text { Hypo- } \\
\text { xanthine }\end{array}$ & $\begin{array}{l}\text { Total } \\
\text { creatine } \\
\text { kinase } \\
{[\mathrm{U} / \mathrm{l}]}\end{array}$ & $\begin{array}{l}\text { Creatine } \\
\text { kinase- } \\
\text { MB } \\
\text { (U/1] }\end{array}$ \\
\hline $\begin{array}{l}\text { Healthy male } \\
\text { adults }\end{array}$ & 180 & $\begin{array}{l}\overline{\overline{\mathbf{x}}} \\
\mathbf{s} \\
\text { range }\end{array}$ & $\begin{array}{l}11.9 \\
4.1 \\
1.7-16.9\end{array}$ & $\begin{array}{l}3.5 \\
0.9 \\
0.2-6.2\end{array}$ & $\begin{array}{l}14.5 \\
4.1 \\
1.9-25.4\end{array}$ & $\begin{array}{l}0.32 \\
0.23 \\
0.11-1.34\end{array}$ & $\begin{array}{l}47 \\
12 \\
12-117\end{array}$ & $\begin{array}{l}3.0 \\
0.8 \\
1.4-5.2\end{array}$ \\
\hline $\begin{array}{l}\text { Healthy female } \\
\text { adults }\end{array}$ & 145 & $\begin{array}{l}\overline{\mathbf{x}} \\
\mathbf{s} \\
\text { range }\end{array}$ & $\begin{array}{l}10.8 \\
3.6 \\
1.2-16.1\end{array}$ & $\begin{array}{l}3.5 \\
1.0 \\
0.2-5.4\end{array}$ & $\begin{array}{l}12.9 \\
3.6 \\
2.1-22.7\end{array}$ & $\begin{array}{l}0.34 \\
0.17 \\
0.14-0.95\end{array}$ & $\begin{array}{l}41 \\
9 \\
3-96\end{array}$ & $\begin{array}{l}3.3 \\
0.9 \\
1.3-4.8\end{array}$ \\
\hline $\begin{array}{l}\text { Patients with } \\
\text { angina pectoris }\end{array}$ & 45 & $\begin{array}{l}\overline{\mathbf{x}} \\
\mathbf{s} \\
\text { range }\end{array}$ & $\begin{array}{l}11.9 \\
5.0 \\
5.3-17.7\end{array}$ & $\begin{array}{l}3.3 \\
0.9 \\
2.4-6.1\end{array}$ & $\begin{array}{l}15.7 \\
4.5 \\
1.7-23.9\end{array}$ & $\begin{array}{l}0.48 \\
0.26 \\
0.19-1.47\end{array}$ & $\begin{array}{l}51 \\
17 \\
18-125\end{array}$ & $\begin{array}{l}5.7 \\
1.8 \\
2.6-9.5\end{array}$ \\
\hline $\begin{array}{l}\text { Patients with } \\
\text { cerebral insult }\end{array}$ & 19 & $\begin{array}{l}\dot{\overline{\mathbf{x}}} \\
\mathbf{s} \\
\text { range }\end{array}$ & $\begin{array}{l}10.0 \\
4.0 \\
2.3-15.1\end{array}$ & $\begin{array}{l}2.7 \\
0.8 \\
0.4-3.9\end{array}$ & $\begin{array}{l}10.4 \\
3.6 \\
1.3-15.4\end{array}$ & $\begin{array}{l}0.38 \\
0.28 \\
0.13-1.69\end{array}$ & $\begin{array}{l}54 \\
15 \\
11-132\end{array}$ & $\begin{array}{l}3.6 \\
1.4 \\
1.5-6.3\end{array}$ \\
\hline $\begin{array}{l}\text { Healthy adults, } \\
\text { patients with } \\
\text { angina pectoris or } \\
\text { cerebral insult }\end{array}$ & 389 & $\begin{array}{l}\overline{\mathbf{x}} \\
\mathbf{s} \\
\text { range }\end{array}$ & $\begin{array}{l}11.4 \\
4.4 \\
1.2-17.7\end{array}$ & $\begin{array}{l}3.4 \\
0.9 \\
0.2-6.2\end{array}$ & $\begin{array}{l}13.8 \\
4.3 \\
1.3-25.4\end{array}$ & $\begin{array}{l}0.35 \\
0.31 \\
0.11-1.69\end{array}$ & $\begin{array}{l}46 \\
12 \\
11-132\end{array}$ & $\begin{array}{l}3.5 \\
2.3 \\
1.3-9.5\end{array}$ \\
\hline $\begin{array}{l}\text { Patients with } \\
\text { myocardial } \\
\text { infarction }\end{array}$ & 155 & $\begin{array}{l}\overline{\mathbf{x}} \\
\mathbf{s} \\
\text { range }\end{array}$ & $\begin{array}{l}16.2 \\
7.1 \\
1.9-31.8\end{array}$ & $\begin{array}{l}7.6 \\
2.8 \\
0.6-15.3\end{array}$ & $\begin{array}{l}24.5 \\
7.6 \\
3.5-39.6\end{array}$ & $\begin{array}{l}0.64 \\
0.38 \\
0.16-1.98\end{array}$ & $\begin{array}{l}371 \\
139 \\
45-731\end{array}$ & $\begin{array}{l}55.4 \\
11.3 \\
6.3-78.8\end{array}$ \\
\hline
\end{tabular}

$\bar{x}=$ mean

$s=$ standard deviation 
cardial infarction are shown versus those obtained for healthy males, healthy females, patients with angina pectoris and patients with cerebral insult. Table 1 shows the statistical quantities of the distributions, and the statistical quantities of the distribution of the sum (hypoxanthine + xanthine), the ratio (xanthine/hypoxanthine), total creatine kinase activity and creatine kinase-MB activity. The data of the $n=45$ patients suffering from angina pectoris and of the $n=19$ patients suffering from cerebral insult cannot be discriminated from the data obtained for healthy males and healthy females. Sensitivity and specificity of the studied analytes were calculated from the results obtained for the samples from $n=155$ patients suffering from myocardial infarction and the results for the $n=389$ samples combined from the four groups of healthy males, healthy females, angina pectoris and cerebral insult. Hypoxanthine showed a sensitivity of 0.59 for a specificity of 0.90 at a discriminator value of $14.7 \mu \mathrm{mol} / \mathrm{l}$, xanthine a sensitivity of 0.83 for a specificity of 0.90 at a discriminator value of 4.5 $\mu \mathrm{mol} / \mathrm{l}$, the sum (hypoxanthine + xanthine) a sensitivity of 0.77 for a specificity of 0.90 at a discriminator value of $19.7 \mu \mathrm{mol} / \mathrm{l}$, and the ratio (xanthine/hypoxanthine) a sensitivity of 0.35 for a specificity of 0.90 at a discriminator value of 0.78 . The ROC-curves are shown in figure 2 .

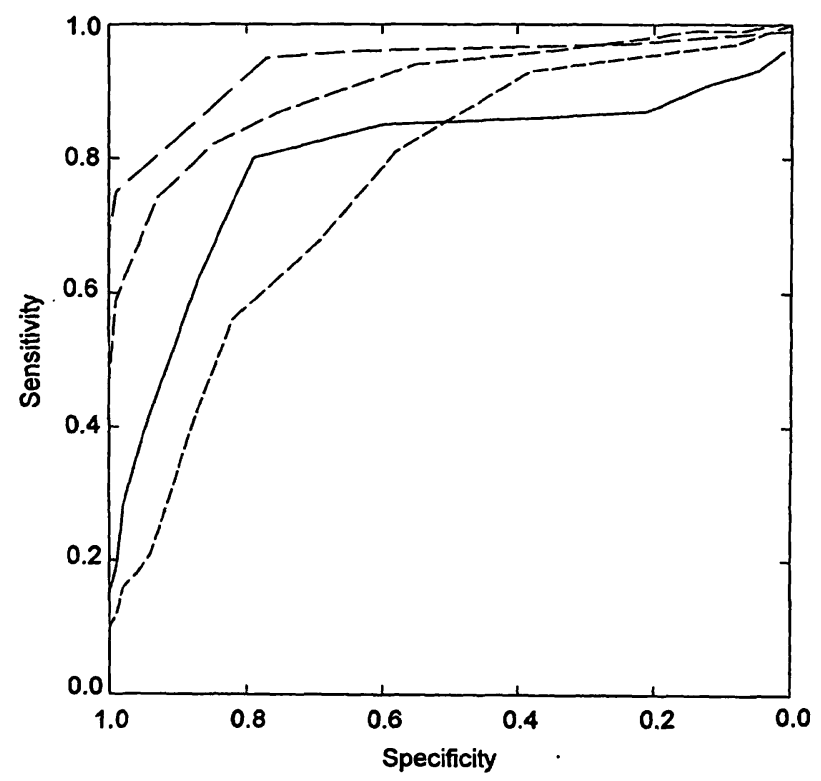

Fig. 2 ROC-curves for serum hypoxanthine concentrations, serum xanthine concentrations, sum (hypoxanthine + xanthine) and ratio (xanthine/hypoxanthine) for the discrimination between a reference collective consisting of the normals, the patients with angina pectoris and the patients with cerebral insult, and the patients with myocardial infarction. The data used for the calculation are those shown in figure $1 \mathrm{a}-\mathrm{d}$.

$$
\begin{aligned}
& - \text { Hypoxanthine } \\
& -\ldots-\text { Xanthine } \\
& ---- \text { Hypoxanthine + xanthine } \\
& -\cdots-- \text { Ratio xanthine/hypoxanthine }
\end{aligned}
$$

\begin{tabular}{|c|c|c|c|c|}
\hline & $\mathrm{n}$ & & $\begin{array}{l}\text { Uric acid } \\
{[\mu \mathrm{mol} / \mathrm{l}]}\end{array}$ & $\begin{array}{l}\text { Allantoin } \\
{[\mu \mathrm{mol} / \mathrm{l}]}\end{array}$ \\
\hline $\begin{array}{l}\text { Healthy male } \\
\text { adults }\end{array}$ & 180 & $\begin{array}{l}\overline{\mathbf{x}} \\
\mathrm{s} \\
\text { range }\end{array}$ & $\begin{array}{l}336 \\
64 \\
185-486\end{array}$ & $\begin{array}{l}16.7 \\
8.3 \\
2.4-41.5\end{array}$ \\
\hline $\begin{array}{l}\text { Healthy female } \\
\text { adults }\end{array}$ & 145 & $\begin{array}{l}\bar{x} \\
\mathbf{s} \\
\text { range }\end{array}$ & $\begin{array}{l}212 \\
71 \\
143-378\end{array}$ & $\begin{array}{l}15.8 \\
7.2 \\
1.8-38.1\end{array}$ \\
\hline $\begin{array}{l}\text { Patients with } \\
\text { angina pectoris }\end{array}$ & 45 & $\begin{array}{l}\bar{x} \\
\text { s } \\
\text { range }\end{array}$ & $\begin{array}{l}292 \\
78 \\
152-503\end{array}$ & $\begin{array}{l}17.8 \\
6.8 \\
2.3-36.4\end{array}$ \\
\hline $\begin{array}{l}\text { Patients with } \\
\text { cerebral insult }\end{array}$ & 19 & $\begin{array}{l}\bar{x} \\
s \\
\text { range }\end{array}$ & $\begin{array}{l}267 \\
83 \\
136-450\end{array}$ & $\begin{array}{l}14.9 \\
9.1 \\
1.1-42.6\end{array}$ \\
\hline $\begin{array}{l}\text { Healthy adults, } \\
\text { patients with } \\
\text { angina pectoris or } \\
\text { with cerebral insult }\end{array}$ & 389 & $\begin{array}{l}\bar{x} \\
s \\
\text { range }\end{array}$ & $\begin{array}{l}282 \\
104 \\
136-503\end{array}$ & $\begin{array}{l}16.4 \\
8.4 \\
1.1-42.6\end{array}$ \\
\hline $\begin{array}{l}\text { Patients with } \\
\text { myocardial } \\
\text { infarction }\end{array}$ & 155 & $\begin{array}{l}\bar{x} \\
s \\
\text { range }\end{array}$ & $\begin{array}{l}312 \\
89 \\
171-462\end{array}$ & $\begin{array}{l}18.4 \\
7.7 \\
1.9-34.9\end{array}$ \\
\hline
\end{tabular}

Tab. 2 Results for the determination of uric acid and allantoin. The samples are the same as in table 1 .

$\dot{\overline{\mathrm{x}}}=$ mean

$s=$ standard deviation

Uric acid and allantoin from single serum samples

Table 2 summarizes the data for the determination of uric acid and allantoin from the samples used for the data in figure $1 a-b$. The distribution of the serum concentrations of uric acid and the distribution of serum concentrations of allantoin in the samples from patients with myocardial infarction was not significantly different from the distribution in the samples of the reference collectives.

Release profiles of purines and total creatine kinase/kreatine kinase-MB derived from sera of patients with myocardial infarction

Figure $3 a-b$ shows the data for hypoxanthine, xanthine, total creatine kinase and creatine kinase-MB from serial serum samples, obtained from $n=53$ patients with myocardial infarction, hospitalized at the cardiological intensive care unit between $5 \mathrm{~h}$ and $150 \mathrm{~h}$ after pain onset. For the samples drawn initially ( $=5 \pm 2 \mathrm{~h}$ after pain onset), only the median for the serum xanthine concentration exceeded the discriminator value for a specificity of 0.90 . For hypoxanthine in median of the measured serum concentration fell below the discriminator value for a specificity of 0.9 after $80-100 \mathrm{~h}$. For xanthine, the median of the measured seruim concentration fell below 


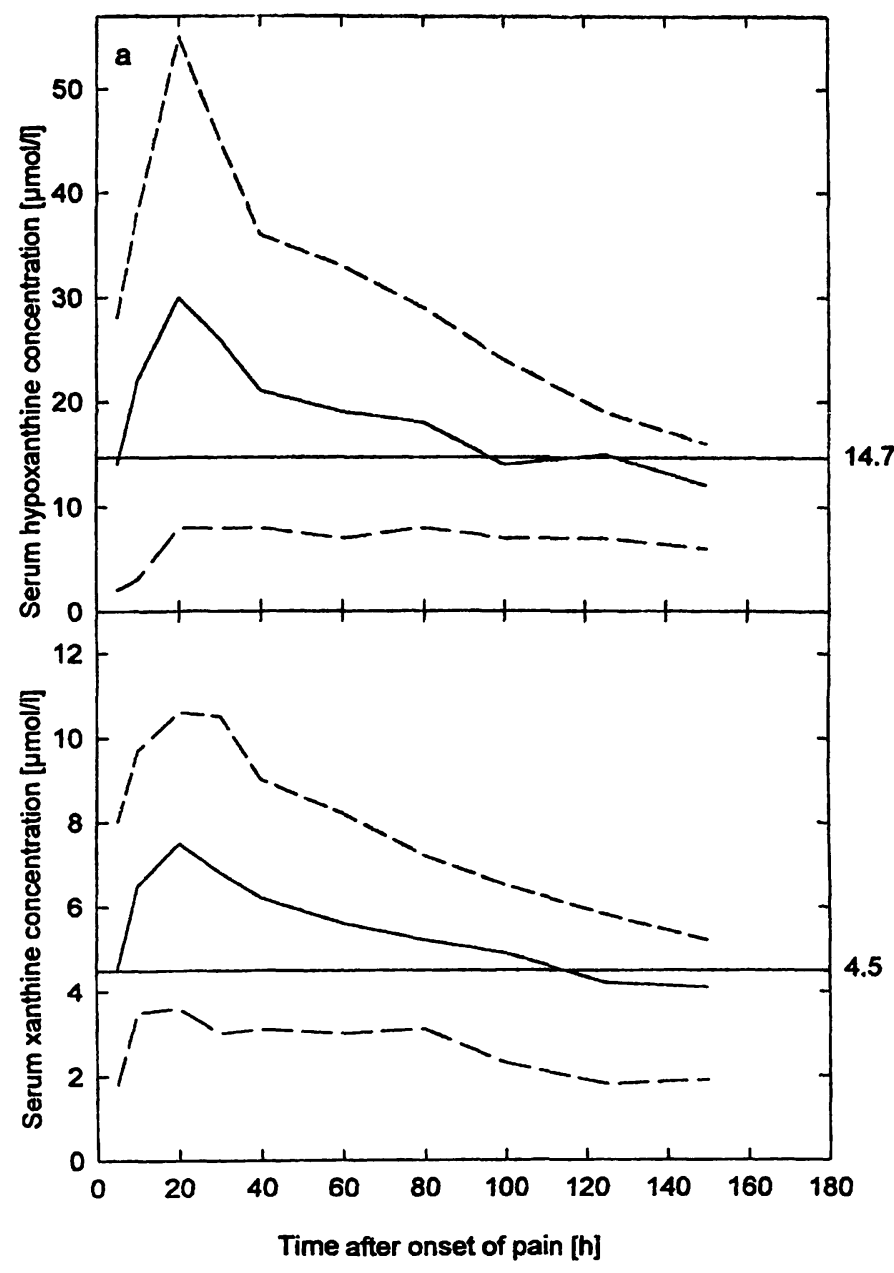

Fig. 3a-b Serum hypoxanthine concentrations, serum xanthine concentrations, total creatine kinase activity and creatine kinaseMB activity determined at different times after pain onset for $n=53$ patients with myocardial infarction. The data are given as

the discriminator value for a specificity of 0.9 after $100-125 \mathrm{~h}$. After $125 \mathrm{~h}$ the median of the total creatine kinase serum activity fell below the upper limit of the reference range used for this method in our laboratory.

\section{Conclusions}

This clinical study of purine metabolism, following myocardial ischaemia resulting from myocardial infarction, was performed in order to elucidate the possible role of xanthine oxidoreductase in tissue alterations in the post-ischaemic phase. During ischaemia there is a calcium-dependent enzymatic degradation of xanthine oxidoreductase from the $\mathrm{NAD}^{+}$-consuming dehydrogenase form to an oxidase form, which directly utilizes molecular oxygen as an electron acceptor in the oxidation of hypoxanthine via xanthine to uric acid $(1,4-5)$. This enzyme could yield very reactive, oxygen-derived radical ions, which could, if not scavenged by appropri-

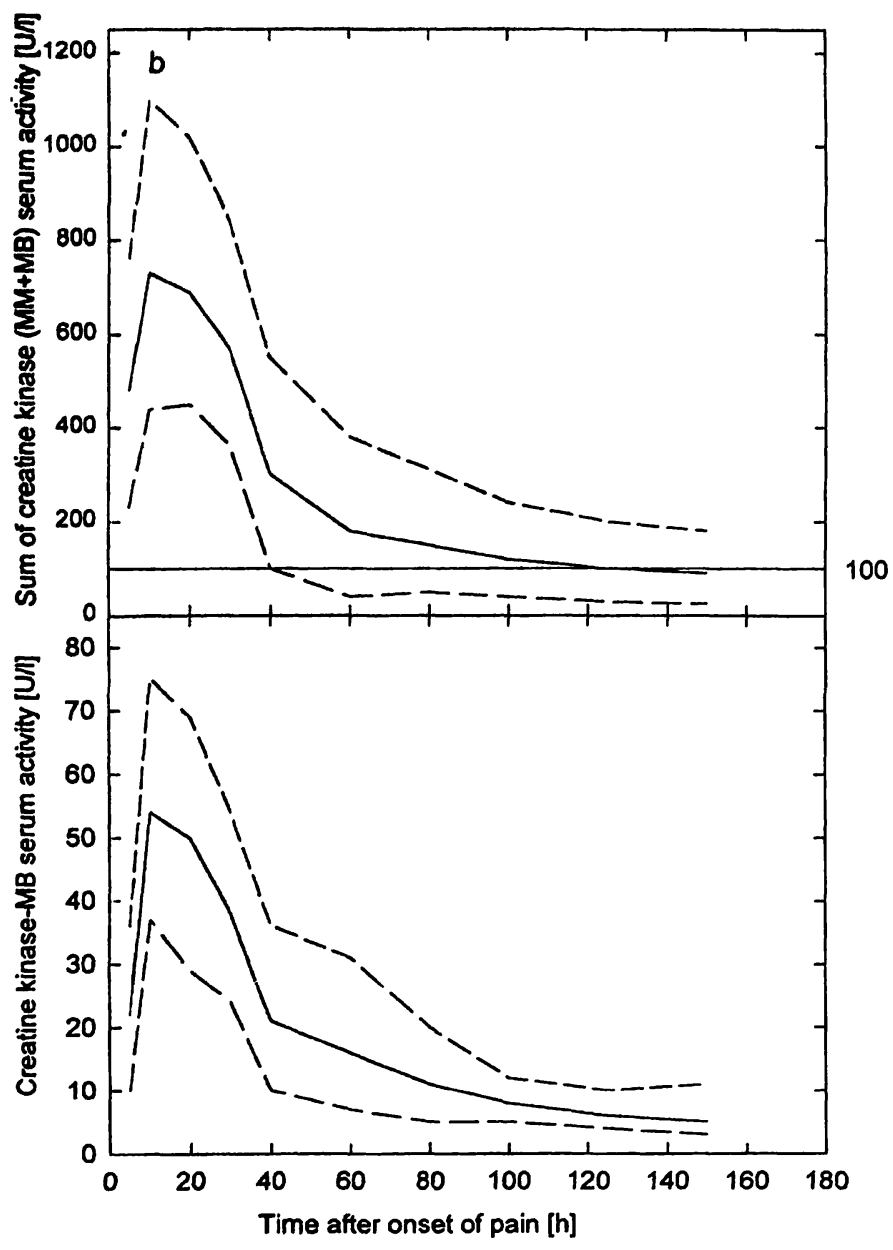

$25^{\text {th }}$-percentile (lower broken line), $50^{\text {th }}$-percentile (medium solid line) and $75^{\text {th }}$-percentile (upper broken line). The discriminator values for a specificity of 0.90 are added (right-hand axis, continuous straight line).

ate radical-scavengers, lead to further tissue destruction (6).

To assess the detectability of changes of purine metabolism in myocardial tissue, using peripheral serum samples, the results for serum hypoxanthine, xanthine, the sum (hypoxanthine + xanthine) and the ratio (xanthine/ hypoxanthine) were determined in blood samples of $\mathrm{n}=155$ patients suffering from myocardial infarction versus appropriate reference collectives. The data shown in figure $1 \mathrm{a}-\mathrm{b}$ and summarized in table 1 indicate an increased efflux of hypoxanthine and xanthine from the injured tissue similar to the efflux of creatine kinase. The sensitivity and specificity data calculated from the distributions of purine serum concentrations show that the elevation of the serum xanthine concentration is most specific for the patients with myocardial infarction. The determination of hypoxanthine is much more unspecific; this analyte is subject to preanalytical errors (7), but cell death and damage might also be responsible for an increase of the hypoxanthine serum concentration. 
The derived quantities, the sum (hypoxanthine + xanthine) and the ratio (xanthine/hypoxanthine) are less informative about disease-specific metabolic changes, but the unequivocal increase of serum xanthine must be due to xanthine oxidoreductase activity directly connected with the metabolic changes of myocardial ischaemia. Consequently, the values for xanthine in the samples drawn between approximately 5 hours and 6 days after pain onset (from the patients kept under surveillance after initial hospitalization in the cardiological intensive care unit) show an elevation above a discriminator value required for a specificity of 0.90 for the longest time after pain onset.

The main result of this study is that the xanthine concen= tration measured in serum derived from peripheral blood is significantly increased in samples of patients suffering from myocardial infarction, compared with sera of an appropriate reference collective. The metabolic activity of xanthine oxidoreductase in myocardial infarction has therefore been proven in this study, and the fact that the release of xanthine persists for four to five days after pain onset on a level above the normal range, supports the role of xanthine oxidoreductase, which has been previously and controversially suggested (9-14).

On the other hand, the existence of oxygen-derived radicals was not supported by examination of a radical-scav-

\section{References}

1. Mc Cord, J. M. (1987) Oxygen-derived radicals: A link between reperfusion injury and inflammation. Fed. Proc. 46, 2402-2406.

2. De Scheerder, I. K., van de Kraay, A. M. M., Lamers, J. M. J., Koster, J. F., de Jong, J. W. \& Serruys, P. W. (1991) Myocardial malondialdehyde and uric acid release after short-lasting coronary occlusions during coronary angioplasty: Potential mechanisms for free radical generation. Am. J. Cardiol. 68, 392-395.

3. Kock, R., Delvoux, B. \& Greiling, H. (1993) A high-performance liquid chromatographic method for the determination of hypoxanthine, xanthine, uric acid and allantoin in serum. Eur. J. Clin. Chem. Clin. Biochem. 31, 303-310.

4. Iriyama, K. (1987) Uric acid in ischemic tissue. Jikeikai Med. J. 34, 145-168.

5. Mc Cord, J. M. \& Fridovich, I. (1968) The reduction of cytochrome c by milk xanthine oxidase. J. Biol. Chem. 243, $5753-5760$.

6. Mc Cord, J. M. (1985) Oxygen-derived free radicals in postischemic tissue injury. N. Engl. J. Med. 312, 159-163.

7. Boulieu, R., Bory, C., Baltassat, P. \& Gonnet, C. (1983) Hypoxanthine and xanthine levels determined by high-performance liquid chromatography in plasma, erythrocyte, and urine samples from healthy subjects: The problem of hypoxanthine level evolution as a function of time. Anal. Biochem. 129, 398-404.

8. Grootveld, M. \& Halliwell, B. (1987) Measurement of allantoin and uric acid in human body fluids. Biochem. J. 243, 803-808

9. Betz, A. L., Randall, J. \& Martz, J. (1991) Xanthine oxidase is not a major source of free radicals in focal cerebral ischemia. Am. J. Physiol. 260 (Heart Circ. Physiol. 29), H563-H568. enging mechanism, the spontaneous oxidation of uric acid to allantoin. Grootveld (8) has shown that allantoin is the best marker for the detection of oxygen-radical induced spontaneous oxidation of uric acid and therefore the best index for the activity of uric acid as a radicalscavenger. Table 2 shows that there is no difference between the groups (see tab. 1)' with respect to uric acid or allantoin. But the absence of a response by allantoin only indicates that the oxygen-radicals, if generated, are preferably subject to other radical-scavenging mechanisms, in contrast to the diseases described by Grootveld (8).

Therefore, the clinical relevance of the findings in this study depends on the validity of those results that indicate that the oxygen-consuming $\mathrm{O}$-form of the xanthine oxidoreductase is the predominant form in the later phase of myocardial infarction (15).

For elimination of the remaining ambiguities of the present results, additional studies must be performed to clarify of the origin, the kinetics and the fate of the xanthine oxidoreductase involved in the metabolic changes following myocardial infarction. Additionally, the origin of the purine metabolites that lead to the long-term elevation of the xanthine effusion from the heart must be elucidated.

10. Werns, S. W., Shea, J. J., Mitsos, S. E., Dysko, R. C., Fantone, J. C., Schork, M. A., Abrams, G. D., Pitt, B. \& Lucchesi, B. R. (1986) Reduction of the size of infarction by allopurinol in the ischemic-reperfused canine heart. Circulation 73, 518524.

11. Chambers, D. E., Parks, D. A., Paterson, G., Roy, R. S., Mc Cord, J. M., Yoshida, S., Parmley, L. \& Downey, J. M. (1985) Xanthine oxidase as a source of free radical in myocardial ischemia. J. Moll. Cell. Cardiol. 17, 145-152.

12. Hammond, B., Kontos, H. A. \& Hess, M. L. (1985) Oxygen radicals in the adult respiratory distress syndrome, in myocardial ischemia and reperfusion injury, and in cerebral vascular damage. Can. J. Physiol. Pharmacol. 63, 173-187.

13. Peterson, D. A., Asinger, R. W., Elsperger, K. J., Homans, D. C. \& Eaton, J. W. (1985) Reactive oxygen species may cause myocardial reperfusion injury. Biochem. Biophys. Res. Comm. 127, 87-93.

14. Stoltenberg, L., Rootvelt, T., Øyasaeter, S., Rognum, T. O. \& Saugstad, O. A. (1993) Hypoxanthine, xanthine, and uric acid concentrations in plasma, cerebrospinal fluid, vitreous humor, and urine in piglets subjected to intermittent versus continuous hypoxemia. Pediatr. Res. 34, 767-77.1.

15. Becker, B. J. (1993) Towards the physiological function of uric acid. Free Radical Biol. Med. 14, 615-631.

Dr. R. Kock
Institut für Klinische Chemie
und Pathobiochemie
RWTH Aachen
Pauwelsstraße 30
D-52074 Aachen
Germany

Eur. J. Clin. Chem. Clin. Biochem. / Vol. 32, 1994 / No. 11 ! 